\title{
Fat content of expressed breast milk: a case for quality control
}

\author{
S A SPENCER, D HULL
}

\begin{abstract}
Expressed breast milk used to feed preterm infants is precious and so, despite heterogeneity of composition, all available milk is used. A study of 274 samples of expressed breast milk supplied by preterm mothers and National Childbirth Trust donors showed pronounced variation in fat content as measured by the "creamatocrit" method. This was not due to differences between term and preterm mothers or between transitional and mature milk. The composition was affected by diurnal variation and method of collection. Substantial amounts of fat were also wasted as a result of continuous nasogastric feeding. Several milk samples did not contain enough fat to supply even a fraction of the recommended energy requirements of these infants.

Some type of quality control over samples of expressed breast milk is clearly essential. The creamatocrit method is simple and feasible.
\end{abstract}

\section{Introduction}

The suitability of breast milk for preterm infants is controversial. ${ }^{1}$ Some workers have shown interest in new artificial formulas designed to satisfy the growth and energy requirements of preterm infants, ${ }^{2}$ while those who believe that the unique biological properties of human milk are important have devised systems for collecting and storing this product. Breast milk may be used raw or after heat treatment and with or without bacterial surveillance. ${ }^{3}$ Pooled milk may be used to avoid heterogeneity of chemical composition, ${ }^{4}$ but individual samples may be preferred, ${ }^{5}$ particularly if from the child's own mother. ${ }^{\circ}$ Although the method of collection influences the fat content of breast milk, ${ }^{7}$ because it is so precious all available milk is normally used. In the Nottingham City Hospital neonatal unit individual samples from preterm mothers and National Childbirth Trust donors are fed raw to preterm infants. Casual observation of the milk in giving sets shows that the content of the milk varies widely. Some milk samples are thick, creamy yellow, while others are thin and white. We have therefore measured the variation in fat concentration and hence energy value of this milk.

\section{Patients and methods}

All milk examined was supplied to the Nottingham City Hospital neonatal unit for feeding to preterm infants.
Breast milk donation-Breast milk expressed by hand or with a manual breast pump was donated by mothers of preterm infants to feed their own babies. Spare milk was given to other preterm infants. Extra milk was obtained from healthy donors breast feeding their own full-term infants at home. These donors collected milk in several ways-namely, they expressed either before or after feeding their own infant or from the opposite breast to the one that had been milked. Only one donor collected a mixture of drip and expressed milk, and as the results in these samples did not differ from the group as a whole they were included in the general analysis. Milk was stored in glass or plastic bottles at $4^{\circ} \mathrm{C}$ for up to 24 hours.

Samples-All stored samples were examined once or twice a day. The bottles were well shaken and a sample drawn into a standard heparinised glass capillary tube. Foremilk and hindmilk were compared in six mothers by obtaining capillary samples from the first and last $10 \mathrm{ml}$ of milk expressed from one breast. Two methods of continuous nasogastric feeding of expressed breast milk were simulated, one controlled by an IVAC infusion pump and the other by a syringe pump positioned vertically. Capillary samples were obtained before and after the milk had been dispensed to determine how much fat had been lost in the apparatus. This was repeated six times for each method. Fat concentrations were measured by the "creamatocrit" method of Lucas et al. ${ }^{8}$ The fat layer, including liquid fat when present, was measured with an ordinary plastic ruler, which gave a measurement accurate to the nearest $0.5 \mathrm{~mm}$. The end of the tube was sealed with Plasticine.

Calculations and statistics-The creamatocrit was expressed as a percentage of the total milk sample in the tube to the nearest $0.5 \%$. Milk fat was calculated from the creamatocrit by the formula, fat $(\mathrm{g} / \mathrm{l})=($ creamatocrit $(\%)-0 \cdot 59) / 0 \cdot 146$, and energy content by the formula, $\mathrm{kcal} / \mathrm{l}=290+(68.8 \times$ creamatocrit $(\%)){ }^{8}$ Statistical significance was tested with Student's $t$ test.

\section{Results}

A total of 274 samples were analysed from 21 mothers (those feeding their own preterm infants) and 10 donors (those feeding their own full-term infants at home). The mean creamatocrit was $5.2 \%(31.5 \mathrm{~g} / \mathrm{l})$ for the whole group (table $\mathrm{I})$ and for both donors and mothers when analysed separately. The range was $0 \cdot 5-13 \%$. The large variation was present both between donors and in samples from just one woman (table II). Transitional milk produced three to 10 days after parturition did not differ from mature milk produced from the 11th day: mean creamatocrit was $5 \cdot 3 \pm \mathrm{SD} 2 \cdot 3 \%$ for 69

TABLE II-Distribution of creamatocrit values in 27 samples of expressed breast milk donated by a single mother

\begin{tabular}{|c|c|c|c|c|c|c|}
\hline $\begin{array}{l}\text { Creamatocrit (\%) } \\
\text { No of samples }\end{array}$ & $\begin{array}{l}2 \cdot 1- \\
2\end{array}$ & $\begin{array}{l}3 \cdot 1- \\
2\end{array}$ & $\begin{array}{c}4 \cdot 1- \\
4\end{array}$ & $\begin{array}{l}5 \cdot 1- \\
7\end{array}$ & $\begin{array}{l}6 \cdot 1- \\
9\end{array}$ & $\begin{array}{l}7 \cdot 1-8 \\
3\end{array}$ \\
\hline
\end{tabular}

Department of Child Health, Medical School, Queen's Medical Centre, Nottingham NG7 2UH

$S$ A SPENCER, BM, MRCP, lecturer

D HULL, FRCP, DCH, professor samples of transitional milk and $5 \cdot 2 \pm 2 \cdot 4 \%$ for 200 samples of mature milk. On 29 occasions in 13 mothers we compared two samples obtained during the same morning, between midnight and midday. There was a highly significant difference in fat concentration between the first and second samples, the first sample containing much 
less fat than the second $(t-5.23 ; \mathrm{p}<0.001)$ (figure). Similarly the foremilk invariably contained less fat than the hindmilk. The mean difference was $38 \%$.

A mean of $34 \%$ of the fat in expressed breast milk was lost when using the IVAC infusion pump and a mean of $19 \%$ lost when using the syringe pump.

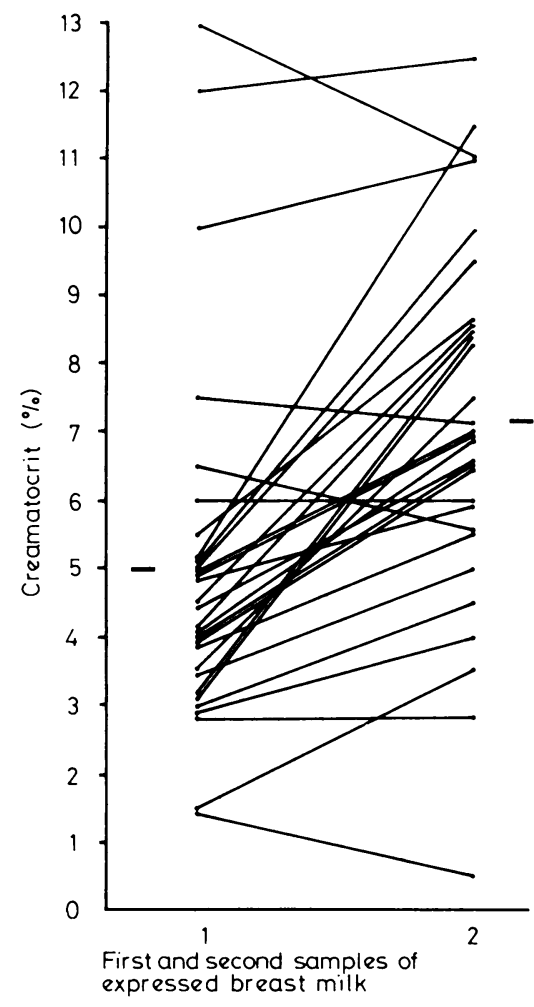

Creamatocrit values in first and second samples of milk expressed during same morning (mean values).

\section{Discussion}

A survey of human drip milk supplied by donors to the milk bank at Leicester Royal Infirmary ${ }^{9}$ showed great variability in fat concentrations, the mean value being only $17 \mathrm{~g} / \mathrm{l}$. We also found considerable variation in individual samples of expressed breast milk, although the mean value was higher $(31.5 \mathrm{~g} / \mathrm{l})$. This variation was not due to differences between preterm and term mothers or differences between transitional and mature milk. Hytten $^{7}$ found that some women are low-fat secretors; he also described a diurnal variation in fat content, the early-morning specimen containing much less fat. We confirmed this diurnal variation as one of the factors in the variations in the creamatocrit of expressed breast milk.

Differing methods of collection also increase variability, as some favour foremilk and others hindmilk. A sucking baby determines its own milk intake to some extent, whereas the preterm infant is not only restricted to the volume it is given but also may be fed on one low-fat sample for a full 24 hours. Furthermore, we have shown that substantial amounts of fat are wasted when drip sets controlled by an IVAC infusion pump are used for continuous feeding. Smaller though still appreciable amounts are lost when using a vertically placed syringe pump. Some at-risk babies therefore receive milk with a much lower energy content than the recommended $100-150 \mathrm{kcal} / \mathrm{kg}(1000$ $\mathrm{kcal} \approx 4 \cdot 2 \mathrm{MJ}$ ). One solution is to use pooled breast milk, but this negates the immunological benefits of using an infant's mother's own milk and requires careful bacterial surveillance: it also requires a banking system, which would be beyond the scope of many small units. The creamatocrit method is a simple and feasible way of exercising quality control over expressed breast milk samples. Altering the technique of collection would ensure that fewer substandard specimens are supplied. Milk with a creamatocrit of $4 \%$ has an energy content of only $560 \mathrm{kcals} / \mathrm{l}$. It seems prudent to discard samples with a lower energy content than this.

\section{References}

1 Fomon JJ, Ziegler EE, Vazquez HD. Human milk and the small premature infant. Am $\mathcal{F}$ Dis Child 1977;131:463-7.

2 Visser HKA. Composition of formulae for low birth weight infants. In: Jonxis JHP, ed. Growth and development of the full term and premature infant. Amsterdam: Excerpta Medica, 1978:163-97.

${ }^{3}$ Anonymous. The special care of human milk. Br Med f 1978;ii:781-2.

4 Williamson S, Hewitt JH, Finucane E, Gamsu HR. Organisation of bank of raw and pasteurised human milk for neonatal intensive care. $\mathrm{Br}$ Med f 1978;i:393-6.

${ }^{5}$ McEnery G, Chattopadhyay B. Human milk bank in a district general hospital. Br Med f 1978; ii :794-6.

6 Baum JD. Preterm milk. Early Human Development 1980;4:1-3.

7 Hytten FE. Clinical and chemical studies in human lactation. $\mathrm{Br} \mathrm{Med} \mathcal{F}$ $1954 ; \mathrm{i}: 176-82$.

${ }^{8}$ Lucas A, Gibbs JAH, Lyster RLJ, Baum JD. Creamatocrit: simple clinical technique for estimating fat concentration and energy value of human milk. $\mathrm{Br}$ Med $\mathcal{F} 1978$;i:1018-20.

9 Davies DP, Carroll L, Derbyshire F. Collecting and banking human milk. Br Med $\mathscr{f} 1980 ; 281: 1350$.

(Accepted 13 November 1980)

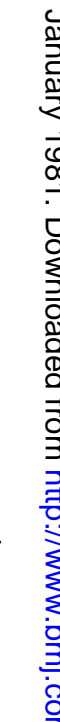

